\title{
LOS LIBROS DE LOS MORISCOS Y LOS ERUDITOS ORIENTALES
}

\section{MORISCO BOOKS AND MIDDLE EASTERN SCHOLARS}

\author{
Mercedes García-Arenal \\ Fernando Rodríguez Mediano \\ CCHS, CSIC, Madrid
}

Pretendemos, en este trabajo, mostrar cómo la erudición orientalista de árabes cristianos venidos a España desde Oriente (a través de Italia) se aproximó a la literatura de los moriscos, cómo la entendió y para qué la utilizó. Mostramos que estos eruditos, de entre los que elegimos los casos de Marcos Dobelio y Miguel Casiri, no pudieron realizar su trabajo orientalista, que se basa en una fuerte vinculación con los manuscritos árabes de la Biblioteca de El Escorial, sin evitar el problema morisco en forma de su producción escrita aparecida en diversos fondos requisados por la Inquisición. Sus saberes y su actividad sirven para trazar los contornos amplios de una historia intelectual de la lengua árabe en Europa, en la que el hecho morisco es interpretado en función de sus variables lingüísticas y doctrinales, a partir de la constitución de una disciplina erudita (el orientalismo), en medio de las polémicas religiosas entre Reforma y Contrarreforma, a partir, en fin, de la historia de la disidencia religiosa y del escepticismo en la Europa Moderna.

Palabras clave: Marcos Dobelio; Miguel Casiri; moriscos; libros árabes; aljamiado; orientalismo; escepticismo.
The aim of this paper is to show how the Orientalist scholarship of Christian Arabs who had come to Spain from the Middle East (via Italy) addressed the literature of the Moriscos, to examine how it was understood by such scholars and what they used it for. We show that these scholars, from among whom we have chosen the examples of Marcus Dobelius and Miguel Casiri, could not carry out their Orientalist work using the Arabic manuscripts of the El Escorial library without confronting the Morisco problem in the form of Morisco texts held in several collections confiscated by the Inquisition. The knowledge and activities of these Moriscos served to trace the broad outlines of an intellectual history of the Arabic language in Europe, in which Morisco activity was interpreted in relation to its linguistic and doctrinal variables. This was achieved by means of the construction of a scholarly discipline (Orientalism) at a time of religious polemic between the Reformation and the CounterReformation, i.e. during the period of the development of religious dissidence and skepticism in early modern Europe.

Key words: Marcus Dobelius; Miguel Casiri; Moriscos; Arabic books; Aljamiado; Orientalism; Skepticism.

* Este trabajo ha sido realizado en el marco del proyecto "Orientalismo e historiografía en la cultura barroca", dirigido por F. Rodríguez Mediano (HUM207-60412/Filo). 
En 1623, Bernardo de Aldrete escribía desde Córdoba, de cuya catedral era canónigo, a Cristóbal de Aybar, el secretario del arzobispo granadino don Pedro de Castro (1539-1623), acerca de una hoja de papel escrita en árabe que le había llegado y que pertenecía a un lote de libros árabes recién encontrados en Pastrana. Decía:

En Pastrana avía gran número de moriscos. Con su expulsión entraron a havitar sus casas cristianos viejos, i con aver tantos años, en una casa no avían echado de ver un aposento, tan bien cerrado estava i dispuesto, que no se entendía que lo avía allí hasta que por coniecturas fueron buscando, i rompieron la pared i hallaron una pieça buena con sus estantes y librería mui bien enquadernada, i entre libro i libro sus papeles blancos, todos en gran número árabes. Hasta aquí me an dicho, i para señas un pedaço de hoja de uno de buena letra, en las que las diferencian algunas de las que ponen las artes. Buen papel, parecen oraciones. Como vino a Córdoba esta hoja, irían otras a otras partes. En Baeça, derribando una pared también apareció otro libro árabe que enviaron a la Inquisición. Cada día se irán descubriendo tantos como tenían los moriscos escondidos. Los de Pastrana dicen que es mucha cosa ${ }^{1}$.

En esta misma carta, Aldrete se manifestaba muy interesado por adquirir libros del librero de Sevilla Juan Bellero, en particular las obras de Druso «i aquel gran herege, Guillielmo Postelo, De Phoenicum Literis». En otras cartas de esta misma correspondencia con Cristóbal de Aybar, al saber del fallecimiento del racionero de la catedral de Sevilla Luis de San Llorente, se interesaba de inmediato por la suerte de sus libros, mostrando particular empeño en conseguir un manuscrito de Flavio Dextro ${ }^{2}$.

Aldrete, ansioso y frustrado en su deseo de conseguir libros, se manifiesta apesadumbrado por la suerte de este lote de Pastrana, y en una carta posterior se lamenta:

${ }^{1}$ Rodríguez Mateos, J. (ed.), Un epistolario de Bernardo José Aldrete (16121623), Sevilla, 2009, carta n. ${ }^{\circ}$ 67, 215. Efectivamente, en Hornachos se encontraron en las casas de los expulsados "muchos libros de religión musulmana, alcoranes rubricados con letras coloreadas y azules, con curiosas pinturas y caracteres que, siendo cosa natural a sus costumbres, pareció a los cristianos viejos prueba de sus perjurios y desmanes, considerándolos no pocos como obras de brujería y encantamientos”, Janer, F., Condición social de los moriscos en España, Valencia, 1857, Junta de Andalucía, 2006, p. 117.

${ }^{2} \mathrm{Ibid}$, cartas n. ${ }^{\circ} 59$ y 60 . Sobre el falso cronicón de Dextro y la conexión de su autor, el jesuita Jerónimo Román de la Higuera, con el asunto de los Plomos del Sacromonte, véase García-Arenal, M. y Rodríguez Mediano, F., "Jerónimo Román de la Higuera and the Lead Books of the Sacromonte", en K. Ingram (ed.), The Conversos and Moriscos in Late Medieval Spain and Beyond, Leiden, 2009, 243-268.

Al-Qanțara (AQ) XXXI 2, julio-diciembre 2010, pp. 611-646 ISSN 0211-3589 
Caso lastimoso lo de los libros árabes, que son tan costosos como escritos todos de mano, i no dexará de aver libros de importancia. I todos los avrán desperdiciado, si no los recogieron para sepultarlos con los de Mulei Cidán en El Escorial ${ }^{3}$.

Aldrete sabía bien la suerte que esperaba a los libros árabes en España, tanto los requisados por la Inquisición, como los que estaban guardados en El Escorial y que provenían, en su mayor parte, del robo en 1611 de una nave del sultán de Marruecos. La biblioteca de Mawlāy Zaydān constaba de más de 4000 volúmenes, y acabaría integrando el cuerpo principal de la colección oriental de la Biblioteca Real a la que se había incorporado en 1614. La correspondencia de Aldrete trasluce la frustración y la decepción de algunos eruditos ante colecciones de libros árabes que se dispersaban, se destruían o se sepultaban en sótanos de la Inquisición o en bibliotecas reales ${ }^{4}$. En este momento en el que estaba conformándose el moderno arabismo europeo, uno de los mayores obstáculos con los que se enfrentaban los estudiosos, sobre todo de los países del Norte de Europa, era el acceso a textos árabes, cuya búsqueda se había convertido en una auténtica obsesión para gente como William Bedwell o Thomas van Erpen. En España, por el contrario y como veremos, los eruditos no podrán nunca evitar el problema morisco en forma de la producción escrita de los moriscos o copiada y transmitida por ellos, pero también por la desconfianza acerca de unos textos cuya lengua, cuyo alfabeto incluso, se asociaba indisolublemente con el Islam. Y es que a diferencia del resto de Europa, en España

\footnotetext{
${ }^{3}$ Rodríguez Mateos, Un epistolario, carta n. ${ }^{\circ}$ 68, 219. Ana Labarta recoge la curiosa y significativa anécdota de los presos moriscos Jaime Alturi y Salvador Zuncar a los que el alcaide de la cárcel les quitó un corán que tenían bajo la almohada. Zuncar se había hecho con ese corán después de preso «de un rincón donde ay muchos libros sueltos» y como estaban "podridos en el aposento pasavan tiempo en leer algunas vezes en el dicho libro»; Labarta, A., "Inventario de los documentos árabes contenidos en procesos inquisitoriales de moriscos valencianos conservados en el Archivo Histórico Nacional de Madrid", Al-Qantara, I (1980), 125.

${ }^{4}$ Es conocida la pasión libresca de Aldrete. Como escribía, tras su muerte, Pedro Díaz de Rivas a Martín Vázquez Siruela (Córdoba, 21 de febrero de 1642): «La librería del $\mathrm{d}^{\text {or. }}$ Aldrete quedó por su testamento a los cartujos, cumpliendo en todo con su condicion natural de guardar en vida y en muerte sus libros, pues regateava de modo el prestar un libro exquisito que me obligava a no pedírselo jamás. Y así por intercessión de un amigo le pedí al Nubiense i saqué a la letra lo de España y un epítome de lo demás», Papeles varios de Martín Vázquez Siruela, Biblioteca Real de Palacio, ms. II/158. Es de señalar, también, la alusión al uso que se hacía en estos círculos eruditos de la traducción latina de al-Idrīsī, que se conocía con el nombre genérico de El Nubiense.
} 
aparecían verdaderas bibliotecas árabes pero éstas contenían otro tipo de obras, otro tipo de literatura árabe que no era la que buscaban Erpenius y Bedwell. Parte ineludible de la actividad de estos eruditos orientalistas consistiría en catalogar los libros requisados por la Inquisición, por un lado, y los fondos escurialenses, por otro. Para los orientalistas que vamos a considerar, eruditos venidos de Oriente ${ }^{5}$, estos libros no se veían como parte de la literatura árabe clásica: eran otra cosa. El presente artículo intenta aproximarse a cómo la erudición orientalista se enfrentó a la literatura morisca, cómo la captó e interpretó y cuáles fueron la consideración y los usos que dio a las colecciones de libros moriscos.

En la anterior cita de la carta de Aldrete se formula el tema de que es objeto el presente artículo, el de la aprehensión de la cultura morisca por la erudición orientalista de época moderna. Con este objeto, pasaremos revista a este descubrimiento de libros en Pastrana, estudiados en su día por Marcos Dobelio y también a otros posteriores, en los que estuvo implicada una figura tan notable como Miguel Casiri (m. 1791). Tanto Marcos Dobelio como Casiri eran cristianos orientales, pasaron por Roma, y tuvieron que enfrentarse a esta literatura morisca a partir de su formación erudita, literaria y lingüística, que les ligaba a su origen oriental, y también a su relación con el orientalismo europeo. Ambos, además, tuvieron una relación singular con los fondos árabes de la Biblioteca de El Escorial. En el cruce entre una cultura orientalista formada entre Oriente y Europa, y la cultura local de los moriscos, queremos mostrar, para comenzar, hasta qué punto el asunto de los Libros de Plomo del Sacromonte supuso un giro en el orientalismo español y en la consideración de los libros en árabe así como el papel desempeñado en este proceso por eruditos cristianos árabes venidos de Oriente a través de Italia $^{6}$.

\footnotetext{
${ }^{5}$ Es difícil encarecer la importancia de la aportación de los cristianos orientales al desarrollo de la erudión orientalista en la Europa Moderna. Por citar sólo tres referencias bibliográficas, Gemayel, N., Les échanges culturels entre les maronites et l'Europe. Du Collège de Rome (1584) au Collège de Ayn-Warqa (1789), Beirut, 1984; Hamilton, A., "Eastern Churches and Western Scholarship", en A. Grafton (ed.), Rome reborn. The Vatican Library and Renaissance Culture, Washington-New Haven-London-Vatican City, 1993, 225-249; o, en este mismo volumen, la contribución de B. Heyberger.

${ }_{6}^{6}$ Propuesta que forma parte del argumento principal de García-Arenal, M. y Rodríguez Mediano, F., Un Oriente español. Los moriscos y el Sacromonte en tiempos de Contrarreforma, Madrid, Marcial Pons, 2010.
} 


\section{Bernardo de Aldrete y Marcos Dobelio}

Bernardo de Aldrete, una figura de extraordinaria relevancia intelectual en la España de su tiempo (1560-1641), conocía, al parecer, el hebreo, el caldeo y el árabe. Gozó de notable reputación como erudito, anticuario y experto en lenguas clásicas y orientales, reputación a la que contribuirían tras su muerte Nicolás Antonio y Gregorio Mayans. Su obra más famosa, Del origen y principio de la lengua castellana o romance que oi se usa en España, publicada en Roma en $1606^{7}$, fue la primera en argumentar detalladamente la procedencia del castellano como lengua derivada del latín, lo cual le hizo establecer una polémica con Gregorio López Madera, que defendía que el español procedía directamente de la Torre de Babel, y entrar con ello de lleno en las polémicas suscitadas por el hallazgo del Pergamino de la Torre Turpiana y de los Libros de Plomo del Sacromonte de Granada. A pesar de su posición acerca del origen del castellano, que evidentemente contradecía la autenticidad del Pergamino (que contenía un texto castellano supuestamente fechado en el siglo I), Aldrete fue un defensor, en la órbita del arzobispo de Granada Pedro de Castro, de la autenticidad de los hallazgos ${ }^{8}$. Al servicio de Castro estuvo siendo éste arzobispo de la ciudad y a él dedicó su obra Varias antigüedades de España, África y otras provincias, publicada en Amberes en 1614. Bernardo de Aldrete nunca llegó a tener, como él se temía, acceso a los libros de Pastrana, pero sí lo tuvo, por el contrario, otro personaje también conectado con el asunto del Sacromonte, el cristiano kurdo llamado en España Marcos Dobelio, que había venido a España desde Roma en 1610 a ocuparse de las traducciones de los Libros de Plomo ${ }^{9}$.

Marcos Dobelio es uno de los personajes más interesantes entre quienes estuvieron en contacto con los Plomos. Tanto su biografía como su formación intelectual y teológica, que poco tenía que ver

${ }^{7}$ Ed. y est. de L. Nieto, Madrid, 1975.

${ }^{8}$ La postura del Aldrete respecto a los Libros de plomo y su relación con Pedro de Castro ha sido pormenorizadamente estudiada por Woolard, K.A., "Bernardo de Aldrete, humanista y laminario", en M. Barrios Aguilera y M. García-Arenal (eds.), Los Plomos del Sacromonte. Invención y tesoro, Valencia-Granada, 2006, 271-295.

9 Rodríguez Mediano, F. y García-Arenal, M., "De Diego de Urrea a Marcos Dobelio, intérpretes y traductores de los Plomos", en M. Barrios y M. García-Arenal (eds.), Los Plomos del Sacromonte, 297-334. 
con la de otros traductores o intelectuales que participaron en los acontecimientos del Sacromonte, dan a su obra un carácter singular y sumamente notable. Su condición de cristiano oriental, que había pasado una temporada en Roma, donde había llegado a ser profesor de árabe en La Sapienza ${ }^{10}$, le hizo considerar a los Plomos como una auténtica aberración, no sólo desde el punto de vista lingüístico o teológico, sino también por el tipo de religiosidad que inspiraban, en el marco de una ciudad tan singular como Granada. Dobelio había seguido a don Pedro de Castro a Sevilla en 1610, donde había trabajado en la traducción del Pergamino y de varios libros plúmbeos, pero sus versiones, que se alejaban mucho de las anteriores, desagradaron pronto al Arzobispo, y el propio Dobelio acabó pronto convencido de la falsedad de los originales. Para demostrarla, escribió un texto titulado Nuevo descubrimiento de la falsedad del metal hasta ahora desaparecido y del que sólo se ha conservado una "Introducción" que, a pesar de su carácter sumario, es uno de los textos más importantes producidos en torno a los Plomos y constituye en sí misma una obra de singular importancia ${ }^{11}$. Tras su alejamiento de don Pedro de Castro, Dobelio realizó varios trabajos como arabista, enseñó árabe a Francisco Gurmendi y al Marqués de Estepa, estudió los contratos y documentos árabes de Granada y Toledo y colaboró largamente con la Inquisición, con cuya protección contó. De hecho, su colaboración con el Santo Oficio le permitió, como veremos, tener acceso a libros moriscos que inspiraron su obra crítica contra los Plomos.

El Nuevo descubrimiento de la falsedad del metal es un texto interesantísimo que refleja, entre otras cosas, la formación literaria árabe de Dobelio, tan diferente de la de otros expertos españoles que se acercaron a los Plomos. En una buena medida, sus intereses intelectuales le acercaban al tipo de saber orientalista que estaba formándose en Europa (y no tanto en España) en ese tiempo. De hecho, sabemos que en 1613, estando ya en España, tuvo contacto epistolar con Isaac Casaubon, el célebre historiador y erudito ginebrino emigrado a Inglaterra, amigo de William Bedwell, comunicán-

\footnotetext{
${ }^{10}$ Las huellas de su trabajo en la Biblioteca Vaticana, así como los datos que conocemos sobre este periodo inicial de su biografía, han sido señalados por Levi della Vida, G., Ricerche sulla formazione del più antico fondo dei manoscritti orientali della Biblioteca Vaticana, Ciudad del Vaticano, 1939, 268 y ss., y 280-285.

${ }^{11}$ Utilizamos el ms. 285 de la Biblioteca de Castilla-La Mancha, en Toledo.
} 
dole su ruptura con el arzobispo don Pedro de Castro y su intención de establecerse también en Inglaterra, en un ambiente que estaba dando origen al gran orientalismo inglés del s. XVII, a partir de esa figura fundacional que fue Bedwell ${ }^{12}$.

Esta intención de trasladarse a Inglaterra no se cumplió nunca, pero seguramente no es un azar que en la Bodleian Library de Oxford se encuentren dos documentos importantes para conocer la trayectoria profesional de Dobelio en España y, sobre todo, la amplitud de su saber orientalista ${ }^{13}$. Uno de ellos es una "Lista de los libros árabes que están en la Biblioteca del Rey de España" (Fihrist al-kutub al- 'arabiyya allatī fì maktabat Sulțān Ispāniyā), uno de los primeros repertorios de los manuscritos árabes de la Biblioteca Real de El Escorial, que consta de 251 entradas, ordenadas alfabéticamente (según el alfabeto latino); se trata de un elenco muy sumario, más bien un documento de trabajo o un resumen. Más interesante es el otro documento, una lista de sus propios libros árabes, dirigida a un corresponsal anónimo (quizás Casaubon o Bedwell), a quien informa de los libros que tenía en Sevilla, añadiendo que había dejado en Roma hasta 72 libros de teología cristiana de los santos padres ${ }^{14}$. Se trata de una lista escrita en latín, en la que se pueden identificar diccionarios y libros de gramática y de lexicografía (los de alF̄ìñzābādī, al-Ŷawharī, Jalīl b. Ahmmad, Ibn al-Hāâyib, Ibn al-Āŷurrūm, Ibn Mālik, Abū 'Ubayda), de retórica (al-Šarîf al-Radīi), de ciencia (Averroes, Avicena, al-Rāzī, al-Zahrāwī), de filosofía (Aristóteles, alAbharī), de poesía (al-Mutanabbīi, Șafî l-dīn al-Hillīi, Ŷamīl al- 'Udrīi, Ibn al-Fāriḍ, Ibn Sūdūn) y métrica (quizás el Kitāb al-Maqṣad de Jalīl), de literatura (como las polémicas entre la pluma y la espada de Ibn Burd al-Aṣgar y de Ibn Nubāta), de historia (Abū l-Fidā), de arte militar (al-Hasan al-Rammāḥ), de Corán y hadiz (al-Bujārī), una biografía de Muhammad, espejos de príncipes (al-Ṭuțūšš), una gran cantidad de obras de al-Suyūṭ̂..., además de un buen número de libros cuya identificación es más problématica, y que tratan distintos

${ }_{12}$ Levi della Vida, Ricerche, 283; Hamilton, A., William Bedwell the Arabist (15631632), Leiden, 1985, 18, 33-34.

13 "Index [i.e., catalogus] librorum [manuscriptorum] Arabicorum qui sunt apud Marcum de Obelio", followed by another similar list of Mss. belonging to the King of Spain, Bodleian Library, Colección Ushler mss., Mss. 27619, ff. 174-181.

${ }^{14} \mathrm{Ibid}$., f. 176r. Un estudio más desarrollado de estos documentos puede encontrarse en García-Arenal y Rodríguez Mediano, Un Oriente español, cap. 9. 
aspectos como la criptografía (Tractatus de enigmis et cifris), la geografía (Liber geographiae et corographiaem auctore Abi Zacharia Benamolia quo discribuntur habitus, ritus, mores diversarum gentium et res mirabilis fontium fluminum, arborum, animalium et multa alia elegantissimo sermone), la historia (Historia Regum Persarum, Historia Regum Dimasci, Historia Regum Babiloniae qui fuerunt triginta sex, Historia terrae santae et de bello sabito inter Saladinum et Gallos cum descriptione machinarum bellicarum), biografías diversas (de Abū Bakr al-Rāzī, de Aristóteles, de Sócrates, de Platón o de Apolonio de Perga), la fisiognomía (Benhabas de Physonomia omnium gentium) o la astrología (Astrologia iudiciaria Ptholomei)... Una biblioteca, pues, muy amplia e importante, sobre todo teniendo en cuenta las circunstancias de la época. Se trata de un momento crucial del desarrollo de unos estudios árabes propiamente modernos en Europa, un momento que coincide con la formación y catalogación de los primeros grandes fondos de manuscritos orientales en Italia o España, en los Países Bajos o en Inglaterra. Esta lista es importante también porque muestra la formación orientalista de Dobelio y el tipo de obras que manejaba y que conformaban sus referencias y sus instrumentos de trabajo.

En su "Introducción" al Nuevo descubrimiento de la falsedad del metal, Dobelio da cuenta del hallazgo de los libros de Pastrana del que hablaba Aldrete, deteniéndose de manera especial en los que él mismo utilizó. Se trata de un uso interesante porque, según su propio testimonio, Dobelio sólo pudo comprender enteramente los textos de los Libros Plúmbeos, su origen y los ingredientes de que se componían, después de que el inquisidor general don Pedro Pacheco, obispo de Cuenca, pusiera a su disposición un lote de libros que los moriscos, recién expulsados por aquellos años posteriores a 1610, cuando Dobelio escribía, habían dejado abandonados en una bodega de una casa en Pastrana ${ }^{15}$. Son estos libros, gran parte de

15 «[...] que este Pentateuco es muy antiguo y como le faltan dos hojas a la postre, no puedo poner la fecha; el qual se halló con differentes libros mahometanos y otros de filosophía, geometría, medecina, gramática y defferentes vocabularios, que tuue orden de escoger los mejores para la Biblioteca Oliuariense, siendo Jnquisidor General el $\mathrm{Il}^{\mathrm{mo}}$. $\mathrm{S}^{\mathrm{r}}$. Don Pedro Pacheco, Obispo de Cuenca, tío del Sr. Don Pedro Pacheco, que al presente reside en el dicho Consejo con grande integridad y satisfaçión de todos, a cuyo cargo está este negocio de las láminas, el qual con grande vigilançia y cuidado defiende la verdad. Y como este libro con los demás mahometanos que çitamos en este discurso 
cuyos títulos Dobelio dice que hasta entonces desconocía porque no se encontraban en la Biblioteca Vaticana ni en ninguna en la que hasta entonces él hubiera trabajado, los que le permiten realmente entender y percibir las raíces y el contexto de la fabricación de los Plomos. Estos «diferentes libros mahometanos» encontrados en Pastrana incluían títulos de «filosofía, geometría, medicina, gramática y diferentes vocabularios, que tuve orden de escoger los mejores para la Biblioteca Olivarense» ${ }^{16}$. De estos libros extrae Dobelio sus principales argumentos para demostrar que los Libros de Plomo eran una falsificación morisca, comenzando por la lengua en que estaban escritos, pues

cómo puede el autor dar prueba de ser árabe oriental, nacido y criado en Arabia en los tiempos de César Augusto o de Tiberio, y no repara que escribe y habla como occidental idiota y bárbaro, lengua común a todos los ignorantes y vulgares árabes de Occidente, como se puede enseñar en diferentes libros escriptos en España de personas que no servían ni tenían regla en el componer y menos en el escribir ${ }^{17}$.

Nótese la consideración que le merece esta lengua árabe occidental degradada y corrupta, acervo de gentes vulgares e ignorantes, «idiotas» (es decir, analfabetos) y bárbaros.

\section{Los libros de Pastrana y Marcos Dobelio}

Efectivamente, de este lote de libros de Pastrana y de otro encontrado anteriormente en la misma localidad, tenemos noticias no sólo por Aldrete y Dobelio sino por la documentación inquisitorial. Son las siguientes:

estauan en poder de los moriscos, los quales en el tiempo de su expulsión dexaron enterrados en Pastrana dentro de una cueua, pareze que el autor de las láminas sigue el estilo destos libros de donde tiene sacado toda su Doctrina, como lo demostraremos y tenemos demostrado», Dobelio, M., Nuevo descubrimiento, Ms. 285, Biblioteca CastillaLa Mancha, f. 73-74.

${ }^{16} \mathrm{Ibid}$, f. 73. Don Pedro Pacheco había proporcionado otros libros a Olivares. En particular, en 1624 le remitió una bellísima Biblia romanceada, hoy conocida como "Biblia de la Casa de Alba", que estaba depositada en el Santo Oficio. De Andrés, G., "Historia de la biblioteca del Conde-Duque de Olivares y descripción de sus códices", Cuadernos Bibliográficos, 28 (1972), 4.

${ }^{17}$ Ms. 285, Biblioteca Castilla-La Mancha, ff. 40-41.

Al-Qanțara (AQ) XXXI 2, julio-diciembre 2010, pp. 611-646 ISSN 0211-3589 
En 1631, es decir, cuando hacía tiempo que se había saldado la expulsión de los moriscos, comisarios del Tribunal de la Inquisición de Toledo realizaron una visita a los territorios de su jurisdicción. Entre otras localidades, visitaron la villa alcarreña de Pastrana y allí les informaron de que «con anterioridad» se habían encontrado ya por dos veces libros arábigos «en mucha cantidad» en casas que dejaron los moriscos expulsos, por lo cual el Santo Oficio pidió oficialmente, desde Toledo, información a la villa de Pastrana ${ }^{18}$. El arcediano Alonso de Cifuentes dio fe de que un lote se había encontrado hacía unos 16 años (es decir, en torno a 1615) y otro hacía 9 años, en 1622, en casas del barrio de Pastrana llamado Albaicín, poblado principalmente por moriscos de Granada deportados a Castilla en 1570 a raíz de la guerra de las Alpujarras:

libros en lengua arábiga encuadernados y con una funda de faxos de damasco azul y colorado y franjas de oro que no se acuerda cuántos serían, en una casa que dejaron los moriscos pegada al huerto de los frailes de San Francisco.

Los libros se encontraron en una bodega, en unos saquillos con espliego (para preservar de la humedad) y había entre ellos también libros en castellano. Efectivamente, en esta carpetilla de documentación inquisitorial que estamos utilizando ${ }^{19}$ se incluye un documento que atestigua que ya en 1622 el Duque de Pastrana había avisado al inquisidor general del hallazgo de estos libros, y que le había enviado «seis tercios» de ellos. Por las cuentas del carretero que los transportó, y que cobró al peso, se sabe que estos seis tercios de libros pesaron 28 arrobas, lo cual significa un lote muy considerable. Es sin duda de este hallazgo de 1622 del que hablaba la correspondencia de Aldrete.

Dobelio afirma que escogió los mejores ejemplares de entre aquellos que catalogó para el Santo Oficio (catálogo o lista que no hemos encontrado) y que éstos fueron depositados en la Biblioteca Olivariana, pero que él, Dobelio, se fijó sobre todo en los libros que le permitían comprender el contexto y las fuentes moriscas de los Libros de Plomo del Sacromonte en los que estaba trabajando. Por desgracia, Dobelio no incluye en su texto un inventario completo de los libros que le pasó el inquisidor Pacheco. La información que so-

18 AHN, Inquisición, Leg. 3105, 1, 23 abril 1631. Hemos estudiado este caso en García-Arenal y Rodríguez Mediano, Un Oriente español, cap. 10.

${ }_{19}$ AHN, Inquisición, Leg. 3105. 
bre algunos de ellos nos proporciona es, como vamos a ver, tan tentadora como escasa. Menciona casi exclusivamente aquellos libros que él ha utilizado para cotejar e iluminar su interpretación de los Plomos como factura morisca, y especifica que todos los libros que usa y menciona en su tratado (y por lo tanto en su "Introducción") pertenecen al lote encontrado en Pastrana. Las obras y autores que menciona más frecuentemente son al-Gazālī, el Kitāb al-šifā' del $q \bar{a} d \bar{l}$ 'Iyāḍ, el Kitāb al-anwār de al-Bakrī (del que nos dice que era un libro muy viejo, ennegrecido y manoseado, de más de 300 años), gracias al cual muestra cómo las historias de Jesús que relatan los Plomos no son sino historias del profeta Muhammad. Los libros de «nigromancia, de encantos y de supersticiones» que tratan de los sigilos, de los planetas «donde pone el sigilo de la Luna en figura exagonal, como hace el autor de las Láminas», le sirven también para identificar la proveniencia formal de los círculos de Plomo, su escritura y sus signos, entre ellos un Kitab al-asrār o "Libro de los secretos" ${ }^{20}$. Utiliza, sobre todo, las obras de Qișas al-anbiyā' o "Historias de los profetas" de al-Ta labī y de Ibn Watīma, con las que coteja la historia del Sello de Salomón tal y como figura en los Plomos, demostrando que se trata de la legendaria historia islámica de Salomón y de su anillo, aquel que le permitía dominar a los demonios y que le proporcionaba conocimiento esotérico ${ }^{21}$. El anillo tenía un sigilo que «era de figura exágona» y tenía escrito «no hay Dios sino Dios, uno solo y sin compañero ni participante. Mahoma es su siervo y mensajero» ${ }^{22}$.

20 «Entre otros libros que tratan de cosas superstiçiosas hallo uno muy antiguo intitulado كتاب الاسر ار في فنون مذاهب الثطار و هم الطياليق Libro de los secretos de differentes maneras de operaçiones de los Príncipes de los Demonios, donde introduçe un Príncipe dellos llamado Phitecus, y diçe hauer sido el primero que dio obediencia al Rey Salomón aconsejándole que llamase a su presençia los .72. Príncipes de las Legiones para interrogar a cada uno de por sí del daño que haze al género humano, y que enseñe el remedio. Todos estos después de hauer entrado a su presençia diçen el mal que hazen, después dan el remedio de cosas naturales acompañadas de caracteres, nóminas, sigilos, y palabras superstiçiosas del Alcorán; donde se descubre hauerlo compuesto algún mahometano y para acreditar su patraña, lo apoya al Rey Salomón», Dobelio, Nuevo descubrimiento, f. 32.

${ }^{21}$ Philippe Roisse, en su edición y traducción del libro de Plomo, muestra hasta qué punto este libro sigue la historia legendaria de Salomón recogida por la literatura árabe, en particular la difundida por el género conocido como Qișaș al-anbiya ${ }^{\prime}$. Roisse, $\mathrm{Ph}$., "La Historia del sello de Salomón. Estudio, edición crítica y traducción comparada", en M. Barrios y M. García-Arenal (eds.), Los Plomos del Sacromonte, 141-171.

${ }^{22}$ Dobelio, Nuevo descubrimiento, f. 138. 
Y utiliza el Pentateuco en árabe hallado también en Pastrana para demostrar que la historia de Moisés que aparece en los plomos no procede del Éxodo, sino de la versión coránica de la historia de Moisés y de las "historias de los profetas" ${ }^{23}$. De igual modo, se sirve abundantemente de un "libro de sermones" titulado Kitāb zād al-wāiz wa-rawd al-hăfiz o "Libro del viático del predicador y jardín del estudioso" ${ }^{24}$ y «trasladado» (es decir, copiado) por un Aḥmad b. Qāsim b. Ahmad b. al-Hasan b. 'Umar, natural de Almazán ${ }^{25}$, a quien no hemos podido localizar.

Sobre todo, Dobelio argumenta detalladamente acerca de las concordancias de parte del texto de los Plomos con el Kitāb al-anwār de al-Bakrī, un autor oriental del siglo XIII del cual halló un ejemplar en árabe entre los libros de Pastrana. Este libro fue extraordinariamente popular entre los moriscos como prueban las varias versiones aljamiadas que se conservan hoy día, procedentes de hallazgos en Ricla, Uclés o Urrea de Jalón ${ }^{26}$. Fue incluso refundida en una versión versificada por un morisco aragonés, Mohamad Rabadán, y difundida a su vez en esta forma ${ }^{27}$. Se trata de un pormenorizado estudio de la genealogía del profeta Muhammad, con sus gloriosas hazañas, y de toda su descendencia, relatadas en clave legendaria. Para los moriscos suponía un engrandecimiento, no sólo del linaje de Muhammad, sino del de todos los musulmanes. Un linaje sagrado que acercaba a éstos a su Creador más que ningún otro pueblo y unas hazañas gloriosas que hablaban de un pasado triunfante. De la difusión de que gozó este Libro de las luces dan también fe los procesos inquisitoriales, sobre todo por el éxito que tenían las victorias pasadas de los musulmanes, «nuestras gloriosas gestas pasadas» ${ }^{28}$. Las celebracio-

${ }^{23}$ Dobelio, Nuevo descubrimiento, ff. 70 y ss.

${ }^{24}$ Ibid., f. 112.

${ }^{25}$ Ibid., f. 161.

${ }^{26}$ Lugo de Acevedo, M.L. (ed.), El Libro de las luces. Leyenda aljamiada sobre la genealogía de Mahoma, Madrid, 2008.

${ }^{27}$ Lasarte, J.A., Poemas de Mohamad Rabadán. Canto de las lunas. Día del juicio. Discurso de la luz. Los nombres de Dios, Zaragoza, 1991, 73-270; Corriente, F., Relatos píos y profanos del manuscrito aljamiado de Urrea de Jalón, prólogo de M Jesús Viguera, Zaragoza, 1990.

${ }^{28}$ Como es el caso quizá de Francisco de Espinosa, de El Provencio (Cuenca), que «leía en un libro cosas de Mahoma [...] especialmente cómo había ganado y señoreado muchas tierras», mientras la concurrencia de moriscos «se holgaba mucho» con ello; García-Arenal, M., Inquisición y moriscos, los procesos del tribunal de Cuenca, Madrid, 1978, 87. Lo mismo en Aragón, donde varios procesos incoados a moriscos especifican 
nes entre los moriscos de la noche del mawlid, es decir, la conmemoración de la natividad del Profeta, incluían lecturas en voz alta de fragmentos del Libro de las luces ${ }^{29}$, como atestiguan diversos procesos inquisitoriales procedentes de lugares cercanos a Pastrana ${ }^{30}$. La versión de al-Bakrī encontrada en Pastrana estaba en árabe: no se encuentran entre el lote alcarreño escritos aljamiados, que normalmente no fueron utilizados por los moriscos granadinos, que usaban el árabe. Los datos que da Dobelio sobre esta versión árabe del Libro de las luces nos permiten pensar que se trata de la versión actualmente conservada en la Biblioteca Vaticana ${ }^{31}$.

En el Libro de las Luces, los temas tan preciados por los moriscos acerca de su ascendencia sacra, de sus linajes gloriosos, de las hazañas realizadas en un pasado portentoso, quedaban especialmente amplificados y daban respuesta, entre otras cosas, a la alegación cristiana del origen bastardo de los descendientes de Ismael, hijos de la esclava Agar. Como dice Dobelio, el texto del Libro de las Luces

descriue la descendençia de Mahoma, su nasçimiento y milagros con infinitas patrañas donde se puede ver que todo lo que el autor habla de Nuestro Señor Jesús es de Mahoma encubierto debaxo del nombre de Jesús.

Es decir, Dobelio mantiene que determinados sectores de los Plomos, y muy en particular el libro titulado Vida y milagros de Cristo, son un traslado del libro de al-Bakrī que se limita a atribuir las historias de Muhammad a Jesús: que se ha «disfrazado», pues, a Muhammad bajo la apariencia de Jesucristo.

que el acusado leía el Libro de las luces, Fournel-Guerin, J., "Le livre et la civilisation écrite dans la communauté morisque aragonaise (1540-1620)", Mélanges de la Casa de Velázquez, 15 (1979), 251.

${ }_{29}^{29}$ Sobre esta cuestión de la celebración del mawlid, así como del gusto en círculos sufis por la lectura del Kitab al-anwār, véase Shoshan, B., "Al-Bakrī's biography of Muhammad", en Popular culture in Medieval Cairo, Londres, 2002, 37 y ss. Véase también, Kaptein, N.J., Muhammad's Birthday Festival, Leiden, 1993, 129 y ss.

${ }_{30}$ Dressendörfer, P., Islam unter der Inquisition. Die Morisko-Prozesse in Toledo (1575-1610), Wiesbaden, 1971, 84.

${ }_{31}$ Este mss. fue llevado a Roma en 1627 por el nuncio en Madrid Camillo Massimo. Dicho nuncio trajo de España al vaticano veintiún manuscritos árabes. Lugo de Acevedo, El libro de las luces, "Introducción", 41. P.S. Van Koningsveld ha puesto de manifiesto cómo los manuscritos árabes traídos de España a la Vaticana proceden en su mayoría de la Inquisición, Van Koningsveld, P.S., "Andalusian-Arabic Manuscripts from Christian Spain. A Comparative Intercultural Approach", IOS, 12 (1992), 75-110. 
Procedente del lote de manuscritos de Pastrana, encuentra Dobelio la "epístola apostática del perverso hereje Abinagiomoa, natural de la villa de Almagro, aveçindado en la çiudad de Orán, essortando la morisma de España, Vniuersis et singulis, que puedan conuersar con los cristianos, tanto en las cosas sacras como en las prophanas sin cargo de consçiencia y guardar su ley enteramente" ${ }^{32}$; una "epístola" que, según nos dice, traslada enteramente y comenta por lo menudo en la versión integral, por desgracia nunca encontrada, de la Falsedad del metal. No nos dice si la encontró en árabe o en castellano, pues existen numerosas versiones y copias de esta «epístola» de la que habla Dobelio, que no es sino la famosa fatwà del muftí Abū l-'Abbās Aḥmad Ibn Ab̄̄ Ŷum a al-Magrāwī (m. 1511). Es decir, la respuesta jurídica expedida desde el Magreb en 1504 (poco tiempo después del decreto de conversión al cristianismo) en respuesta a la petición de unos moriscos de España que le solicitaban su opinión sobre la licitud de permanecer en tierra de cristianos. Es un documento importantísimo porque da licencia a los musulmanes de España para vivir en el disimulo de sus creencias y de su religión, manteniendo ésta exclusivamente en su interior y plegándose al cumplimiento exterior del catolicismo, sin perder por ello su condición de musulmanes. La fatwà mantenía y argumentaba esta licitud en contra de otros ulemas que le habían precedido y que se habían pronunciado al respecto, como es el caso del jurista de Fez Aḥmad al-Wanšarīsī quien, unos años antes y en torno a la misma cuestión, había declarado la obligatoriedad de emigrar de España para todos aquéllos que quisieran seguir siendo considerados como musulmanes ${ }^{33}$. Esta famosa respuesta del llamado «muftí de Orán» constituye, realmente, uno de los textos teológicos más importantes para la historia del islam tardío español; para Dobelio implica, además, la legitimación de esta literatura islamizante secreta que él ve en los Plomos, el compendio todo de sus objetivos. Dobelio llama «apóstata» al autor de la fatwà pensando que debía tratarse de un morisco, dado su patronímico al-Magrāwī que, para él (y puesto que se halla en presencia de un lote de libros moriscos) señalaba un ori-

${ }^{32}$ Ibid., f. 49.

${ }^{33}$ La bibliografía sobre esta fatwà es enorme. Remitimos a uno de los últimos títulos que utiliza una bibliografía muy extensa: Stewart, D., "The identity of the "muftī of Oran', Abū-l-'Abbās Aḥmad b. Ab̄̄ Jum ah al-Maghrāwī al-Wahrānī (d. 917/1511)", Al-Qantara, XXVII (2006), 265-301. 
gen de la villa de Almagro, una equivocación derivada de su poco conocimiento del Magreb o del Islam occidental. La nisba alMagrāwī se refiere en realidad, como es obvio, a una tribu bereber situada entre Orán y Marruecos a la que el muftí sin duda pertenecía, aunque era él un ulema de $\mathrm{Fez}^{34}$. Un manuscrito de la Biblioteca Nacional de Madrid, descrito por Saavedra, dado por perdido y luego adquirido por Gayangos (tenemos noticias de su adquisición en Londres) ha sido recuperado recientemente entre los fondos de la Real Academia de la Historia: corresponde con el que debió de pertenecer a Dobelio y formar parte de sus escritos en conexión a los Plomos ${ }^{35}$. Según la descripción de Saavedra ${ }^{36}$, este compendio llevaba el título general de Tractados contra el corán e incluía tres obras: Lumbre de la fe contra el Alcorán, Vida y milagros de Cristo N.S., por Thesiphón Abenathar, discípulo de Jacobo el Apóstol y la Epístola mahomética del Apóstata. Esta versión lleva el título en español, escrito por una mano más tardía que podemos suponer de Dobelio, y que añade: «es una carta de Obaydala Ahmed Abenabigiomoa, natural de Almagro y avecindado en Orán». Si releemos el texto de la fatwà del muftí de Orán después de leer la argumentación de Dobelio en su escrito sobre la Falsedad del metal, podemos comprender la impresión que la «epístola» causaría en el erudito oriental: todos los temas por él denunciados como eludidos en los Plomos son precisamente aquellos que el muftí aconseja disfrazar o evadir ${ }^{37}$. Dobelio pone de manifiesto las semejanzas entre la "epístola" y los Plomos: dos textos que apoyan el disimulo de los moriscos en su observancia clandestina del Islam.

34 Como ha demostrado D. Stewart en el artículo citado.

35 Véase Villaverde Amieva, J.C., "Los manuscritos aljamiado-moriscos: hallazgos, colecciones, inventarios y otras noticias", Memoria de los moriscos. Escritos y relatos de una diáspora cultural, Madrid, 2010, 101. También Ruiz García, E., "Ante la próxima edición de dos tratados antialcoránicos: Juan Andrés (1515) y Joan Martín de Figuerola (mss. inédito de la RAH)", Aljamía, 15 (2003), 82-92.

36 Saavedra, E., "Discurso", Memorias de la Real Academia Española, VI, Madrid, 1889, Apéndice, 314-315.

37 El texto de la fatwà ha sido varias veces publicado y traducido de sus diversas versiones. Utilizamos la reproducida en García-Arenal, Los moriscos, Madrid, 1975, 43 y ss. Una versión en inglés en Harvey, L.P., Muslims in Spain (1500-1614), Chicago y Londres, 2005, 60 y ss. 


\section{Muḥammad Alguazir o Diego Alguacil}

Pero lo que convierte el texto de Dobelio en lo que finalmente es, un tratado de polémica anti-islámica, un tratado de controversia de carácter histórico-filológico y de hermenéutica, es, además de la lectura de esta "Epístola", la de otro de los libros aparecidos en Pastrana que él titula Libro de la disputa contra los judios y cristia$n o{ }^{38}$ de cuyo autor no nos dice más que «se conoce que fue árabe español docto no sólo en la sagrada escritura, pero también de la lengua hebrea». Siguiendo obviamente las pautas de esta Disputa, Dobelio responde a una serie de cuestiones que él asocia a los Plomos. En particular, Dobelio se interesa por los atributos que hay en el tratado y que en los Plomos aparecen asignados a Jesucristo, «nombres de Mahoma encubiertos debajo del nombre de Jesús» entre los que se cuenta «efuelgemit, que quiere decir el que divide entre las criaturas y los animales [...] y en la Escritura se llama el prometido, que quiere decir el que saca los hombres de las tinieblas y los lleva a la Luz». Este «efuelgemit» es el Paráclito. Para Dobelio está claro que el libro de Disputa que él mismo ha encontrado entre los fondos de Pastrana defiende la idea de que Muhammad es el Paráclito anunciado por las Escrituras, «el prometido». «Esto dice el autor del Libro de la disputa contra los Judíos y Cristianos provando con autoridades del Testamento viejo y nuevo cómo todos hablan de Mahoma que es el prometido»; y añade:

dice también este autor (el del Libro de la disputa) que por el Parácleto se entiende Mahoma prometido en los Evangelios y se ve que el original de las Láminas está mal traducido diciendo en lugar de Alphareclit (al-fariqlit) que es el Paráclito usando el vocablo griego como suelen hazer los árabes en los libros que han traduçido de la escritura en su lengua, y no es efuelgemit ${ }^{39}$.

Nótese esta referencia de Dobelio a las traducciones del griego al árabe, realizadas en Oriente y que él conoce. Esa idea de Muhammad como Paráclito le parece a Dobelio que está en el tejido, en el trasfondo de los Plomos. En puridad, el Paráclito, en la ortodoxia cristiana, es el Espíritu Santo, pero en la polémica islámica contra el cristianismo, su sentido de «el prometido» o «el invocado» se identi-

${ }^{38}$ Dobelio, Nuevo descubrimiento, ff. 80 y ss.

${ }^{39} I d$., f. 81 y ss.

Al-Qanțara (AQ) XXXI 2, julio-diciembre 2010, pp. 611-646 ISSN 0211-3589 
fica con Muhammad y es uno de los argumentos recurrentes en la polémica islámica anticristiana, muestra irrebatible, para los musulmanes, de que en las Escrituras cristianas se anuncia la llegada del Profeta $^{40}$. En tiempos moriscos, la idea del Paráclito adquiere un carácter mesiánico. Según ha demostrado Gerard Wiegers, la idea de Muhammad como mesías surge en medios moriscos de principios del XVII, sobre todo de medios moriscos en el exilio ${ }^{41}$. Por las fechas en las que escribe Dobelio, hay sólo dos textos, que sepamos, que hagan relación explícita a esta idea de Muhammad como mesías, idea que luego informará el apócrifo conocido como Evangelio de Bernabé, también surgido de medios moriscos en el exilio. La primera de esas dos obras de disputa religiosa es la de Juan Alonso Aragonés, un cristiano convertido al islam y exiliado al Norte de África, que escribió una obra de polémica en forma de confrontación entre las creencias de judíos y cristianos con las de los musulmanes, demostrando la superioridad de éstas. Su tratado fue escrito en español, entre 1602 y 1612. Con esta obra podría coincidir el título otorgado por Dobelio a su anónimo tratado de polémica. La otra obra es la de Muhammad Alguazir, morisco de Pastrana, que escribió en torno a 1609-1611 su obra de disputa contra el cristianismo, en español también, según nos dice el autor, a petición del sultán de Marruecos Mawlāy Zaydān ${ }^{42}$, estando avecindado en Marrakech y dirigiéndose a sus congéneres moriscos que habían vivido demasiado tiempo entre cristianos y necesitaban argumentos para reafirmarse en la fe del Islam. Muhammad Alguazir estaba en 1627 en la corte de Marrakech $^{43}$, donde debió de coincidir con al-Ḥaŷarī, que se refiere a

${ }^{40}$ Como demostró ya Mikel de Epalza en su Fray Anselm Turmeda (Abdallāh alTarŷumān) y su polémica islamo-cristiana. Edición, traducción y estudio de la Tuḥa, Roma, 1971, $2^{\text {a }}$ ed. actualizada, Madrid,1994, 34-36. El propio Turmeda desarrolla el tema del Paráclito citando el cap. XV del Evangelio de Juan y aplicándolo al Profeta, ibid., 484-485.

${ }_{41}$ Wiegers, G.A., "Muhammad as the Messiah: a comparison of the polemical works of Juan Alonso with the Gospel of Barnabas", Bibliotheca Orientalis, 52, (1995), 245-291.

42 «Por avérmelo mandado el potentíssimo uirtuosso socorredor y engrandezido justo y ssublimador Rey i gobernador de los moros, Mulei Zaidan», citado por Wiegers, G.A., "The andalusi heritage in the Maghrib: the polemical work of Muhammad Alguazir", Orientations. Poetry, Politics and Polemics. Cultural transfer between the Iberian Peninsula and North Africa, 4 (1996), 107-132, 114.

${ }^{43}$ Según Ibrāhīm al-Taybilī, que le cita como inspirador de su obra: «y abiendo visto un libro que a mis manos bino cuyo autor fue Muhamad Alguaçir, beçino que fue de Pastrana, y al presente de la ynsigne çiudad de Marruecos en que contradiçe la falsa 
él como «nuestro Alguaçil» en una carta escrita a moriscos de Estambul ${ }^{44}$. Muhammad Alguazir alcanzó la notoriedad con esta obra de polémica contra el cristianismo titulada Apología contra la ley cristiana, que fue muy difundida en traducciones latinas. Su carácter profundamente antitrinitario y sus invectivas contra el Papado hicieron que tuviera gran fortuna en círculos protestantes del Norte de Europa. En castellano se conservan dos versiones ligeramente diferentes, ambas en letra del siglo XVII. Una de ellas, en la Biblioteca Nacional de Madrid (BNE 9074), fue descrita por Saavedra y estudiada por Wiegers ${ }^{45}$. La otra se encuentra en Oxford, en Wadham College, y ha sido estudiada por L.P. Harvey ${ }^{46}$. Dados los contactos de Dobelio con Inglaterra cualquiera de las dos versiones podría ser la que se encontró en Pastrana, pero hay que tener en cuenta que la de Madrid incluye un tratadito sobre los atributos de Dios (uno de los temas sobre los que se extiende Dobelio) que no se encuentra en la versión conservada en Wadham Collage, lo cual hace más que probable que sea ésta la que tuvo Dobelio en sus manos. Es de señalar también que la traducción latina de este tratado de Alguazir, cuyo recorrido hasta Europa y sus círculos antitrinitarios ha sido trazada por Wiegers, fue adquirida por John Selden y se conserva también en la Bodleian Library de Oxford ${ }^{47}$.

Muhammad Alguazir debió pertenecer (es nuestra propuesta) a la familia Alguacil, de la cual tenemos varios miembros documentados en Pastrana. Los bienes de moriscos de Pastrana, puestos a la venta en el momento de la expulsión, recogen los nombres de tres moriscos apellidados Alguacil que venden sus casas y sus viñas ${ }^{48}$. En 1613, fue acusado ante la Inquisición Diego Alguacil, denunciado por haber afirmado que sabía escribir oraciones en árabe y «trasladarlas», es decir, traducirlas ${ }^{49}$.

ley cristiana», Bernabé Pons, L.F., El cántico islámico del morisco hispanotunecino Taybilī, Zaragoza, 1989, 140.

${ }^{44}$ Wiegers, "The andalusi heritage", 110.

${ }_{45}$ Saavedra, E., "Índice general de la literature aljamiada", Memorias de la Real Academia Española, IV, 239-240; Wiegers, "The andalusi heritage".

${ }^{46}$ Harvey, L.P., "A second Morisco manuscript at Wadham College, Oxford", AlQantara, X (1989), 257-272.

${ }^{47}$ Wiegers, "The andalusi heritage", 121-130.

${ }^{48}$ Martínez Millán, J., "Los moriscos en Castilla: 'bienes raíces' de los moriscos de la villa de Pastrana", Les morisques et leur temps, París, 1983, 413-430,417.

${ }^{49}$ AHN, Inquisición, Leg. 2106, n. ${ }^{\circ} 13$. 
Si se leen los argumentos de Dobelio, se puede apreciar que éstos coinciden casi punto por punto con el texto de Alguazir y con particularidades de éste que no se encuentran en el texto de Juan Alonso. En particular, la discusión sobre los atributos o șifāt de Muhammad. La discusión acerca de las maneras de expresar la Trinidad de los cristianos antiguos, usando la palabra aqānim, plural de aqnüm o «hipóstasis», que se encuentra expuesta desde puntos de vista opuestos en Alguazir y Dobelio ${ }^{50}$ : es un término muy poco usual en los libros de polémica, pero, según Dobelio, así se hallaba traducida la idea de Trinidad en el Pentateuco que encontró en Pastrana. También se encuentra en Alguazir, y es discutida por Dobelio, la idea de que Cristo no sufrió pasión sino que fue sustituido por Judas, de que Jesús es «espíritu de Dios», rūh Allāh y no «hijo de Dios», la defensa por parte de Alguazir de al-tawhìd, la Unicidad que tanto preocupa a Dobelio y que, según él, está implícitamente mantenida en el texto de los Plomos. Y sobre todo, la idea principal del tratado de Alguazir, a saber, que Muhammad es el mesías anunciado por las Antiguas y las Nuevas escrituras, el Paráclito. Todo ello permite pensar que Dobelio tenía ante sí un ejemplar de la obra de Alguazir. ¿Y cómo había llegado a sus manos? Sin duda, como afirma en repetidas ocasiones de todas las referencias que usa en su Nuevo descubrimiento de la falsedad del metal, porque se encontraba en los fondos de Pastrana. ¿Quiere eso decir que Alguazir escribió su tratado antes de la expulsión y que una vez en Marruecos decidió colocar y difundir su obra bajo el patronazgo de Mawlāy Zaydān? ¿O es acaso posible que Alguazir mandara una copia o una versión de su obra a parientes que hubieran permanecido en Pastrana después de la expulsión? Parece más probable la primera hipótesis, pero ambas son meramente especulativas. No por ello dejan de plantear sugerencias y conexiones sumamente interesantes.

Por ejemplo, una de ellas: Diego Alguacil, ese morisco que acabamos de mencionar, de Pastrana, denunciado ante la Inquisición en 1613 porque un testigo, que era también cristiano nuevo le había preguntado si sabía unas «oraciones de moros». El testigo había comprobado que Alguacil sabía muchas, y ante el asombro que manifestó por este hecho, Alguacil había afirmado: «sí, es verdad que no ay quien sepa más que yo destas cosas y quien tenga mayor memoria

${ }^{50}$ Wiegers, "The andalusi heritage", 117; Dobelio, Nuevo descubrimiento, f. 167. 
que yo para traducirlas», y había continuado diciendo: "ay muchas cosas de verdad entre nosotros de la ley de los cristianos que ay muy poca diferencia de una a otra» y le había referido una copla que decía: «Tanto a las almas alumbras Alcorán que dende el suelo ven las cosas más profundas de la máquina del cielo». Fue mandado a prender por los oficiales de la Inquisición, pero enterado, Diego Alguacil «se huyó» y nunca fue encontrado, razón por la que no se conserva más que las denuncias y la orden de prendimiento. Pues bien, la obra de apologética de Alguazir, como han subrayado sus diferentes estudiosos, usa el término «máquina» para universo, lo cual es notable e infrecuente. Y en el tratado, Alguazir es calificado de «archivo vivo» en cuanto a conocimientos islámicos, es decir, que sabía y tenía en la memoria todo lo referente a la religión del Islam. El manuscrito de Alguazir conservado en Oxford incluye además numerosas «décimas» y «romances», y frases tales como: «su santísimo Profeta Muhamat, siervo y mensajero suyo, luz y luminaria de toda esta máquina» ${ }^{51}$. No es por lo tanto muy aventurado pensar que podemos identificar a este Diego Alguacil, huido de Pastrana en 1613, con Muhammad Alguazir y que es posible que escribiera una versión de su Apología antes de partir al destierro. Wiegers ha propuesto que el tratadito de Alguazir es principalmente un escrito destinado a cristianos desconocedores del Islam e imbuidos de falsas ideas al respecto, deseando combatir la creencia en la Trinidad ${ }^{52}$. Esta propuesta puede quizá reforzarse con esa frase de Diego Alguacil sobre las muchas coincidencias entre ambas «leyes»: «ay muchas cosas de verdad entre nosotros de la ley de los cristianos que ay muy poca diferencia de una a otra». Una forma de hacer proselitismo, de crear un acercamiento de partida con aquellos a quienes se quiere convencer de los errores principales y conducir a la fe en la unicidad de Dios. Una forma, también, de recordar la doctrina de tahrîf, es decir, de que los cristianos habían deturpado y corrompido las Escrituras y de que el mensaje verdadero se encontraba en la versión coránica. Sin embargo, buena parte de la polémica anticristiana de los moriscos es intercomunitaria, es decir, tiene el objeto de reavivar la fe islámica entre los

${ }^{51}$ Harvey, "A second Morisco manuscript", 259.

52 «Para queste livro tenga el fin que se pretende ques descubrir la verdad de la altísima palabra de la unidad, pues por el herror de la trinidad tanta infinidad de almas ban al infierno» según dice el propio Alguazir, Wiegers, "The andalusi heritage", 114, n. ${ }^{\circ} 25$. 
moriscos y proporcionar argumentos para contrarrestar o dar respuesta al adoctrinamiento cristiano. De hecho, y como afirmara Mikel de Epalza, en la España morisca, todos los libros religiosos son polémi$\cos ^{53}$.Y pensamos que el tratado de Alguazir corresponde a esta segunda categoría de tratados de polémica escritos por y para moriscos.

\section{Un medio polémico}

Las propuestas de Alguazir y sus afirmaciones se encuentran expresadas con el mismo fin polémico en procesos de Inquisición de moriscos de la Inquisición de Toledo, es decir, de la misma zona geográfica que Pastrana ${ }^{54}$. Daremos unos cuantos ejemplos que apuntan al medio polémico al que debió pertenecer Alguazir. Así, el caso de Jerónimo de Rojas, un morisco vecino de Toledo condenado por el Santo Oficio, entre otras acusaciones, por afirmar que

es moro y vive en la creencia de la secta de Mahoma porque ésta es la buena, cierta y verdadera creencia para la salvación de las almas y que la ley de Jesuchristo es falsa y engañosa y lo que la Iglesia determina y tiene, errado y sin fundamento y dictado por concilios y juntas que para eso se han inventado el latín para que no se acabe de saber lo cierto que está en lengua arábiga hablado por boca de Dios y que todos los demás libros que se escribieron auctores son mentira e inbenciones que miren las hojas que se han hallado en Granada en arábigo en los libros que el Arzobispo allí ha descubierto en el Monte Santo donde dice Dios que no tubo hijo porque es engaño y que allí el dicho Arzobispo se va enseñándose el arábigo porque ha entendido está errado,

en clara referencia e interpretación polémica de los Plomos granadinos $^{55}$. La versión del tratado de Alguazir conservada en Oxford incide en la afirmación: «Estos artículos de la divinidad (de Cristo) fueron promulgados y ordenados y mandados en el concilio Nizeno, Efesino, Calcidonense y Constantinopolitano, y dando por descomulgados a todos los que no los confesaren y creyeren. Luego sólo son de ley positiva y humana $[\ldots] \gg{ }^{56}$. Harvey resalta, al comentar

${ }_{53}$ Epalza, Fray Anselm Turmeda, 75.

${ }^{54}$ Véase el ejemplo de Lope de Hinestrosa, morisco, vecino de Daimiel procesado por la Inquisición: se le incautó un libro de disputa contra los cristianos escrito en castellano. AHN, Inquisición, Libro 990, f. 364.

${ }^{55} \mathrm{AHN}$, Inquisición, Toledo, Leg. 197, n. ${ }^{0} 5$.

${ }^{56}$ Harvey, "A second Morisco manuscript", 266. 
éste y otros párrafos de Alguazir, el conocimiento que el morisco mostraba de historia eclesiástica. Pero es que los moriscos recurrían a la propia literatura cristiana, aquélla precisamente a la que tenían fácil acceso, para buscar las contradicciones internas del cristianismo y de eso tenemos abundantes pruebas contemporáneas. Los moriscos estaban al tanto e incluso al día de esta literatura cristiana. Como el propio Harvey muestra, Alguazir cita a Fray Alonso de Vascones, que había publicado en Madrid en 1614 (es decir, poco tiempo antes de la redacción de la Apología) un libro titulado Destierro de ignorancias ${ }^{57}$. Del mismo modo que Juan de Sosa, morisco procesado por el tribunal del Santo Oficio de Toledo por dogmatizador y por instruir a moriscos en la ley del Islam, «leía testos de la Biblia» y «leía al Tostado» ${ }^{58}$. Es decir, leía a Alonso de Madrigal, el Tostado, famoso y prolífico teólogo. Por los años en que Sosa fue procesado (1545), el Tostado había publicado una obra en castellano titulada Libro de las paradoxas que trata de las contradicciones de las denominaciones que se encuentran en la Biblia y que el Tostado resuelve siguiendo la hermenéutica medieval. Parece que Sosa leía al Tostado y hacía sus comprobaciones en los capítulos de la Biblia al mismo tiempo.

Es bien revelador de hasta qué punto los moriscos necesitaban ser adoctrinados a contrario el caso de los moriscos que acudían a escondidas a visitar en Carabanchel o en Talavera, al alcaide 'Abd al-Karīm Ibn Tūda, gobernador marroquí de Meknes instalado en España junto a su señor, el candidato al trono marroquí, Muley Xe$q^{5}{ }^{59}$. En 1602, dos moriscos llamados Hernando de Morales y Francisco Hernández, de Ocaña y Pastrana respectivamente, fueron denunciados por otro morisco que les había acompañado a escondidas una noche a visitar al alcaide. Éste les leía en un libro en árabe y luego les explicaba que Jesucristo no había muerto en la cruz, que no hay Trinidad, que Dios no puede tener un hijo, ni hay Espíritu Santo ${ }^{60}$.

${ }^{57}$ Ibid., 262.

${ }^{58}$ AHN, Inquisición, Toledo, Leg. 197, n. ${ }^{\circ} 6$ f. ccxxiii, r.

${ }^{59}$ García-Arenal, M., Rodríguez Mediano, F. y El Hour, R., Cartas Marruecas. Documentos de Marruecos en Archivos españoles (siglos XVI-XVII), Madrid, 2002, 68 y ss.

${ }^{60} \mathrm{AHN}$, Inquisición, Toledo, Leg. 196, n. ${ }^{\circ}$ 3: «Entraron en la casa del alcayde [...] a un aposento donde estaba el dicho alcayde con una ropa de damasco sentado en una cama y se saludaron en algarabía. Se sentaron en unos cogines y platicaron un rato sobre 


\section{También iba a ver a Ibn Tūda el arriba mencionado Jerónimo de Rojas, quien igualmente confesó que bebía vino y comía tocino:}

el dicho alcayde le escupió en el rostro y le riñó y le dixo que no entrase más en su casa ni tratase con los suyos pues no guardaba la ley de sus passados y andaba en el engaño de los cristianos adorando tres dioses, no habiendo más que sólo uno que crió cielos, tierra y elementos y que era disparate decir que Dios tenía hijo, y estaban engañados los cristianos en materia de ayunos [...] y que para prueba deste engaño viesse en el Testamento viejo estaban mandados (los ayunos) hacer, y que con el Concilio Tridentino habían quitado los libros que trataban desto, y que él le mostraría allí luego uno en que lo viesse muy claro que con el mismo havía convencido a cierto religioso su huésped y que el dicho alcayde sacó un libro arábigo y le fue declarando lo que decía en el qual estaba escripto que no había más que un solo Dios y que los ayunos habían de ser de sol a sol y que con esto el dicho Jerónimo de Rojas se humilló al alcayde y pidió perdón y el le consoló diciendo que le perdonaría Dios haciendo dos ayunos cada semana y rescatando algunos esclavos moros y enviándolos a su tierra.

Los casos de estos procesados por la Inquisición ilustran el medio polémico al que perteneció Alguazir, y los libros de Pastrana que describe Dobelio, algunas de las fuentes que pudo tener a mano. El tono de combate y de vehemente indignación de Dobelio en su "Introducción" a la Nueva falsedad del metal da buena muestra de su

que el rey nuestro señor no le daba licencia para pasarse a Berbería porque el suso dicho era juez o gobernador de la ciudad de Mequínez en Berbería, y allí sacó un libro aforrado en carmesí escripto en arábigo con algunas letras de oro y con registros que en caveça dellos tenía una manzana de aljófar del tamaño de un real de a dos y comenzó a leer dicho alcayde dicho libro algunas cosas en algarabía cerrada que éste no entendió más que en general, eran contra nuestra santa Fe Católica [...] que la ley de los moros era la buena y que no se podía salvar en otra, y también dixo allí que Nuestro Señor no había muerto. Luego se quitó la ropa de damasco, se puso una blanca, extendió una pieza de tela blanca en el suelo y comenzó a hacer la zala». Hernando de Morales y Francisco Hernández se quedaron leyendo en el libro. Uno de ellos le dijo al alcayde que le daba cincuenta ducados por el libro. El alcayde preguntó a Vargas si comía tocino y bebía vino, y él contestó que como trabajaba como criado no lo había podido evitar, y entonces el alcayde se volvió a los otros dos y les dijo: «es posible que no os alumbréis unos a otros y que permitáis iros al infierno como os bais» y ellos contestaron, contritos, «no se espante Vuestra Merced que el Reyno es tan estrecho y las penas tan graves que aun a nuestros hijos no osamos a beces boquear». Entonces el alcayde se volvió a Vargas y le comenzó a enseñar una oración que él la quiso escribir en letras castellanas. «Le enseñó que no hay Trinidad y que Dios padre no puede tener hijo, que la redención no puede venir por el que llaman hijo ni ay espíritu santo». A Francisco Hernández la Inquisición le había quemado al padre y tenía un hijo huido porque estaba denunciado a la Inquisición. 
repulsa ante una cultura islámica cuajada de leyendas sobre Muhammad y su familia, de historias legendarias sobre profetas, de magia, escatología y mesianismo, de invitación al disimulo en tanto esos tiempos mesiánicos no lleguen, y sobre todo, de omnipresente polémica. Una literatura lejana, para él, de las autoridades y de las fuentes producidas por los sabios árabes de la cultura clásica, aquellas que interesaban en aquel momento a los eruditos europeos y sobre las que los orientales construían su legitimidad para ser incluidos entre ellos. Una reacción similar a la que tuvo el maronita conocido como arzobispo del Monte Líbano, Yūḥannā al-Hașrūnī, en castellano Juan Bautista el Hesronita, cuando se vio envuelto en las traducciones de los Plomos de Granada. Su correspondencia con el Vaticano denunciando el fraude manifiesta una postura tan escandalizada y alarmada como la de Dobelio ${ }^{61}$. Juan Bautista el Hesronita no se ocupó, que sepamos, de otros libros moriscos que no fueran los Plomos del Sacromonte y por ello no vamos a tratar de él aquí, por más que es una figura sumamente interesante. Sí trataremos, en cambio, del más célebre de los maronitas que trabajaron en España.

\section{Miguel Casiri y los hallazgos de libros moriscos}

Dobelio habla de libros árabes en Pastrana, y de libros escritos en castellano. No hace ninguna referencia a manuscritos aljamiados, bien porque no los hubiera en los que le tocó examinar, bien porque no supiera lo que eran, aunque la Inquisición sabía ya entonces que los moriscos tenían «libros en letra morisca y lengua castellana» además de «libros escritos en letra morisca en arábigo» ${ }^{62}$. Otro es el caso de los libros examinados por Miguel Casiri, como vamos a ver. Y es que más de un siglo más tarde seguían apareciendo lotes

${ }^{61}$ Esta correspondencia, contenida en el Archivio della Congregazione per la Dottrina della Fede, St. R6-a, será estudiada en otro lugar. Nos hemos ocupado del Hesronita en Rodríguez Mediano, y García-Arenal, "De Diego de Urrea a Marcos Dobelio", 297-334.

${ }^{62}$ Así por ejemplo, en el proceso del antes mencionado Lope de Hinestrosa, un testigo «dixo que el libro estaba trasladado de letra morisca y lengua castellana e que tan bien tenía letra morisca el libro escrito en arábigo que lo leía Juan de Aragón e después declaraba lo que quería decir e que este declarante leía en el libro lo que estaba escrito en lengua castellana que lo entendía este declarante». AHN, Inquisición, Toledo, Leg. 197, n. $^{\circ} 5$.

Al-Qanțara (AQ) XXXI 2, julio-diciembre 2010, pp. 611-646 ISSN 0211-3589 
de libros moriscos escondidos, tapiados o enterrados por sus dueños en el momento de la expulsión, como de hecho seguirían apareciendo hasta el siglo XIX, cuando se realizaron hallazgos de la importancia del de Almonacid de la Sierra. Como en el caso de los libros de Pastrana, las noticias son siempre fragmentarias, incompletas. Hablaremos ahora de aquellos que le tocó estudiar y catalogar a Miguel Casiri.

Como se sabe bien, Miguel Casiri fue un cristiano maronita que, tras su paso por el Collegio dei Maroniti de Roma, fue convencido por uno de sus profesores allí, el padre Francisco de Rávago, confesor de Fernando VI, para que viniera a trabajar a España. Su carrera aquí se prolongó desde 1748 hasta su muerte en $1791^{63}$. En un cierto sentido, la importancia de la figura de Casiri, el carácter auténticamente fundador de su obra y de su magisterio, han podido hacer olvidar los paralelos que su carrera profesional presenta con las de otros orientalistas anteriores que trabajaron en España. En efecto, aunque es imposible negar la condición seminal de la Bibliotheca Arabico-Hispana Escurialensis, publicada entre 1760 y $1770^{64}$, podrían señalarse las similitudes de la trayectoria de Casiri con la de Marcos Dobelio: cristianos orientales que, tras su paso por Roma, acaban en España enfrentados a las cuestiones pertinentes del orientalismo español; es el caso, por ejemplo, de la relación de ambos (aunque con distintos resultados) con los manuscritos de la Biblioteca de El Escorial. O, para lo que interesa a este artículo, el encuentro de ambos con la literatura y el islam moriscos.

Se trata de un paralelo, en todo caso, que está lejos de ser casual, y que resulta muy pertinente para el argumento de este artículo. La presencia de cristianos orientales en Europa en época moderna constituye un movimiento con profundas y muy prolongadas implicaciones en el desarrollo de la erudición y de la imprenta orientales europeas. La experiencia personal, la formación lingüísti-

${ }^{63}$ Un repaso a su carrera profesional puede encontrarse en Fernández, P., "Expediente personal de Miguel Casiri en la Biblioteca Nacional", Al-Andalus-Magreb, 4 (1998), 105-133.

${ }^{64}$ Casiri, M., Bibliotheca Arabico-Hispana Escurialensis, sive librorum omnium mss. quos arabice ab auctoribus magnam partem arabo-hispanis compositos bibliotheca coenobii escurialensis complectitur, Madrid, 1760-1770. Sobre el carácter «fundacional», «original» del arabismo español del s. XVIII es ilustrativo el título del trabajo de Fernández, P., Arabismo español del s. XVIII: origen de una quimera, Madrid, 1991. 
ca y teológica de estos expertos, su importancia en la definición de una «lengua árabe cristiana», constituyen un marco ideal para comprender la manera en que un universo erudito orientalista aprehendió una realidad tan específica y cargada de sentido como la de la cultura morisca. Ya hemos visto cómo Marcos Dobelio analizó, desde su propia formación, los textos plúmbeos, su lengua y el tipo de religiosidad vinculado con ellos. Ahora veremos cómo también Miguel Casiri tuvo que vérselas con la literatura morisca.

En efecto, durante el largo periodo profesional de Casiri en España, tuvieron lugar varios hallazgos de librerías y manuscritos árabes y aljamiados. Así, en julio de 1762, unos niños que buscaban nidos de pájaros en las obras de unas casas de Ciudad de Real encontraron «un nicho o hueco» lleno de papeles escritos en arábigo ${ }^{65}$; ese mismo año, en Macastre (Valencia), se encontró otro manuscrito árabe ${ }^{66}$; a comienzos de 1763, en fin, tuvo lugar un importante hallazgo en Muel (Zaragoza): en el hueco de la escalera de una vieja casa del pueblo, con motivo de unas obras, se descubrieron varias decenas de manuscritos arábigos ${ }^{67}$, junto con la quijada de un cuadrúpedo. Aunque no podemos detenernos aquí con detalle en las circunstancias de los hallazgos, las mismas resultan interesantes por distintos aspectos. Así, en el caso de Ciudad Real, un licenciado Antonio Torres, comisario del Santo Oficio, se quedó con varios de los libros árabes encontrados, y los hizo llegar al Tribunal de la Inquisición de Toledo. Cuando el ministro Ricardo Wall los reclamó, el Inquisidor los devolvió a regañadientes, aduciendo que, aunque reconocía que la Inquisición no tenía derecho a quedarse con los libros y papeles encontrados, lo había hecho

${ }^{65}$ V. Archivo de la BNE (BNE-A), BN caja 1/2: "Expediente sobre el hallazgo de ciertos libros arábigos encontrados fortuitamente en Ciudad Real".

${ }^{66}$ BNE-A, BN caja 1/3: "Expediente relativo al hallazgo de un manuscrito arábigo en el lugar de Macastre (Valencia)".

${ }^{67}$ BNE-A, BN caja 1/4: "Expediente sobre el hallazgo de ciertos libros arábigos encontrados fortuitamente en la villa de Muel (Zaragoza) y en otros lugares". El número de los mismos resulta indeterminado: en un informe se habla de «tres [libros arábigos] en folio, de los que he visto uno, y los restantes en quarto, que son hasta 18, según me han asegurado»; en otro, de «onze tomos de a folio patente en idioma arábigo, con sus índices y de ochenta pliegos cada tomo, con cubiertas de Tafilete encarnado, pero tan bien tratados en lo hermoso de la enquadernación, en la limpieza de lo escrito y en el papel o cabretilla, que [...] no se les conoce la antigüedad». Un primer inventario describe 17 manuscritos. El catálogo de Casiri, en fin, enumera hasta 39 manuscritos, más «varios papeles de diferentes materias de poca importancia, pertenecientes al Mahometismo, que están en un legajo separado». 
por cumplir con una parte essencial de su Ministerio, para reconocerlos y examinarlos, porque en la lengua arábiga y en todas se escriven muchos errores y doctrinas mui contrarias a la pureza de nuestra santa fe, y habiéndose descubierto los referidos libros por una casualidad en el hueco de una pared, no es mucho se le ofreciese al comissario si podían ser dignos de prohibirse.

\section{Frente a esta idea, los oficiales regios decían que}

el fin de Su Magestad es el de recojer quantos manuscritos y antigüedades puedan conducir al adelantamiento de las ciencias sin reparar en gastos, esmerándose más particularmente en hacer publicar los escritos árabes que tan olvidados han estado hasta aquí, como se deja ver por la Bibliotheca Árabe que últimamente se ha impreso a expensas de Su Magestad.

Una idea, pues, ilustrada, que estaba detrás de esta búsqueda de manuscritos árabes y, en fin, el gran proyecto de la Bibliotheca Arabico-Hispana Escurialensis. En un cierto modo, esta pugna entre la Inquisición y la Monarquía por el control de estos manuscritos parece reproducir el estatuto confuso de los textos moriscos, entre su carácter doctrinalmente problemático y la idea (típicamente orientalista) de que los libros árabes contenían un saber útil ${ }^{68}$. Pero, ¿contenían estos manuscritos encontrados algo que pudiese contribuir al adelantamiento de las «ciencias» en España?

Evidentemente, la persona indicada para responder a esa cuestión era el propio Miguel Casiri, a quien finalemente fueron remitidos los manuscritos encontrados para su catalogación. Así, sobre el primer manuscrito de Ciudad Real que le fue enviado, Casiri dictaminó que se trataba de

un tratado del Derecho Canónico-Civil mahometano. Convendrá, como Vuestra Excelencia insinúa, ver los demás que se han hallado en Ciudad Real por si huviese entre ellos alguno especial. Por la forma de los caracteres me parece ser escrito dicho códice en el siglo duodécimo al tiempo de Mohamed primero rey de Granada de la familia de Beni Násser ${ }^{69}$.

${ }^{68}$ Este argumento del valor del aprendizaje de las lenguas orientales, y del árabe, como fuente de conocimiento forma parte de un tópico repetido por muchos orientalistas e intelectuales europeos de época moderna al justificar la utilidad de sus estudios, junto con otros vinculados, por supuesto, a la evangelización. V., por ejemplo, para el caso de Erpenius (convertido en un tópico), Van Rooden, P.T., Theology, Biblical Scholarship and Rabbinical Studies in the Seventeenth Century. Costantijn L'Empereur (1591-1648), Professor of Hebrew and Theology at Leiden, Leiden, 1989, 59-60.

${ }^{69}$ Carta de Miguel Casiri a Ricardo Wall, Madrid, 24 de julio de 1763, BNE-A, BN caja $1 / 2$.

Al-Qanțara (AQ) XXXI 2, julio-diciembre 2010, pp. 611-646 ISSN 0211-3589 
Sin embargo, lo que tiene mayor interés es sin duda el catálogo que Casiri realizó de los libros encontrados en Muel. Como ha quedado dicho más arriba, aunque el número de manuscritos encontrados difiere según los testimonios, este catálogo se refiere a 39 manuscritos. Uno de los aspectos interesantes del documento, firmado el 4 de abril de 1763, es que refleja el encuentro de Casiri con el aljamiado. Él mismo lo describe así:

\begin{abstract}
Estos dos tomos ${ }^{70}$ están escritos en lengua castellana alterada y corrompida con caracteres arábigos con tal artificio que uno que no sabe este secreto creerá ser otra lengua desconocida. Es muy difícil leerlos y mucho más entenderlos, por estar ligadas las palabras y escritas con solas letras consonantes. Los moros, ya vasallos de los cristianos, usaban desta lengua y con ella escribían cartas y libros, a imitación de los judíos, que escriben cartas en lengua italiana, castellana, etc., con caracteres rabínicos, para que ningún estraño los entienda. Lo mismo practican los cristianos en la Syria, los quales por lo regular escriben en árabe con letras siriacas o carciúnicas, afin de que los mahometanos no penetren sus secretos ${ }^{71}$.
\end{abstract}

La referencia al karšūni, es decir, al árabe escrito en caracteres siriacos según una práctica que se encuentra documentada entre cristianos orientales desde el s. X, resulta interesante, como pequeña muestra de cómo Casiri interpretaba un fenómeno local español a la luz su propia experiencia «oriental». Luego volveremos sobre este tema. Pero esta cita demuestra, en cualquier caso, que el «descubrimiento» de la aljamía se produjo mucho antes de lo que normalmente se viene dando por establecido.

Por otro lado, el catálogo en cuestión es también valioso porque proporciona una información interesante sobre la cultura literaria morisca. En él se pueden encontrar noticias sobre libros, autores, fechas de copia, etc. A menudo, el catálogo describe sumariamente la forma y el tema de los libros en cuestión, dedicados mayoritariamente, aunque no sólo, a cuestiones religiosas: "Tradiciones maho-

${ }^{70}$ Se refiere a los dos primeros códices de su catálogo, un «Códice $\mathrm{I}^{\mathrm{o}}$.- Derecho canónico y civil de los mahometanos que compreende 98 títulos y 340 hojas. Está en papel grande y no tiene nombre de autor ni fecha» y «II.- Otro tomo también en papel grande, que trata del derecho canónico y civil de los mahometanos en 62 títulos y 160 hojas. No tiene fecha ni nombre de autor».

71 "Catálogo de los códices arábigos manuscritos que he reconocido de orden de $\mathrm{Su}$ Magestad, que Dios guarde, comunicada por el Excelentísimo Señor Don Ricardo Wall en 24 de marzo de este año", Madrid, 4 de abril de 1763, BNE-A, BN caja 1/4.

Al-Qanțara (AQ) XXXI 2, julio-diciembre 2010, pp. 611-646 ISSN 0211-3589 
metanas, en $8^{\circ}$ ", "Colección de varios dichos y hechos de Mahoma, sin nombre de autor ni fecha, en $4^{\circ}$ pequeño", "Preces varias sacadas del Alcorán, en 12", "Cuentos fabulosos y supersticiosos de Mahoma, en $16^{\circ}$ ", "Parte del texto del alcorán en pergamino, en $4^{\circ}$ ", "Capítulos del texto del Alcorán, con su exposición de varios Doctores mahometanos que se nombran en la obra; está en $4^{0 "}$; "Tomo primero de la tradición mahometana, en que se refieren los dichos y hechos de Mahoma que no están escritos en el Alcorán. Su fecha en el año de la hégira 1004, de Christo 1595, en quarto", "Instrucción de lo que deben creer y hacer los mahometanos, sin fecha ni autor, en $4^{\circ}$ pequeño"... En otros casos, describe manuscritos aljamiados: "Tratado de las ceremonias legales, sobre el modo de labarse y hacer la oración, escrito en lengua castellana con letras arábigas, sin fecha ni autor, en $4^{\circ}$ pequeño", "Compendio de los dichos de Mahoma, con su explicación, en lengua castellana con letras arábigas, también en 4", "Tratado moral para instruir a los mahometanos, escrito en lengua castellana con letras arábigas, en 4", "Historia de Alexandro Magno, según la fabulosa tradición mahometana, escrita en lengua castellana con caracteres arábigos: no tiene autor ni fecha; en $4^{\circ}$ pequeño"; "Comentario sobre el texto del Alcorán en lengua castellana con caracteres arábigos en $4^{\circ}$ y escrito el año de la égira 923 y de Christo 1517 '... En otras obras consta el autor y hasta el copista: así, de un ejemplar del Kitāb al-'ayn de Jalīl b. Aḥmad se dice "Diccionario arábigo intitulado Fuente, que es compendio de otro muy antiguo que compuso Jalil Ben Ahmad, insigne maestro en la lengua arábiga, en el año de la égira 71, de Christo 690. El autor del compendio es Mohamed Ben Hafsan Alzobaidi, cordovés, ayo que fue del príncipe Hescham, hijo y sucesor del Rey de Córdova Alhakem Almostanser Billá, de cuya orden lo compiló. Este célebre escritor murió en Sevilla el año de la égira 379, de Christo 989. El códice se escribió en Cervera en el año de la égira 749, de Christo 1348. Tiene muchas adiciones y notas marginales, y por consiguiente es más copioso que el ejemplar que se conserva en el Escurial". De una obra de Averroes, "Tratado de Física, su autor Averroes, natural de Córdova. Este códice tiene a las márgenes algunas notas latinas con letras góticas y otras notas hebraicas". De otra de Algazel, "Tratado espiritual de la felicidad del hombre y del modo de conseguirla, intitulado Balanza de las Obras, su autor Abu Hamed Algazali, doctor célebre entre los Mahometanos; floreció en 
el siglo IV de la égira, fue escrito este códice el año de la égira 899, de Christo 1493, y está en $4^{\circ}$ ". De la obra gramatical (seguramente al-Ŷymal) de al-Zaŷŷâŷ̄i, "Gramática arábiga, su autor Abu Casem Abdelrahman Ben Isac Alzagiagi, escrita en Segorbe el año de la égira 824, de Christo 1421 , en $4^{\circ}$ ". En otros casos, la obra resulta difícil de identificar, a pesar de los detalles aducidos: "Tratado de la herencia, de su división y distribución según los grados de consanguinidad y afinidad, intitulado Suficiente; su autor Abu Hassan Ali Ben Mohamad llamado el Tripolitano. Escribióse y se acabó su copia a medio día el lunes a 15 de octubre del año de la Égira 976 y de Christo de 1568. Está en $4^{\circ}$ ". Pero más significativa para el contenido de este artículo es, quizás, la aparición de un "Tratado dogmático mahometano intitulado Luces; su autor Abulhassan Alansari, natural de Sevilla. No consta el tiempo en que se escribió". No es sencillo identificar de qué obra se trata. Una primera aproximación podría invitar a relacionar el título, "Luces", con el Kitāb al-anwār de al-Bakrī, aunque, evidentemente, los datos de autoría que da Casiri (un sevillano llamado Abu 1-Hasan al-Anșārī) no concuerdan con los del oriental al-Bakrī; además del hecho, claro está, de lo que Casiri entendía como "dogmática" ${ }^{2}$. En todo caso, este catálogo de manuscritos hallados en Muel constituye un valioso testimonio más de la cultura y la religiosidad morisca y, desde luego, del encuentro de un orientalista «oriental» como Casiri con ellas.

¿Cuál era la consideración que tenía Casiri de la cultura morisca? Nos puede dar una pista al respecto su actuación en otro hallazgo posterior a los ya citados. En la propia villa de Muel, en 1775, apareció una decena de manuscritos «entre las ruinas de una casa antigua $\gg{ }^{73}$. Enviados a Casiri para realizar una valoración, éste respondió con una nota, fechada el 30 de diciembre de 1775, y enviada al Bibliotecario Mayor Juan de Santander, en la que decía: «[...] he reconocido los diez códices arábigos, y no trece, según la nota que Vuestra Señoría me remite, y no hallo en ellos alguna cosa de utilidad o importancia, pues todo el contenido de ellos se reduce a unas oraciones supersticiosas propias de los mahometanos. La maior

\footnotetext{
${ }^{72}$ En todo caso, cabe subrayar el hecho de que en esta pequeña colección se encontraban, como se ha dicho, unos "Cuentos fabulosos y supersticiosos de Mahoma".

${ }^{73}$ BNE-A, BN caja 1/4: "Expediente sobre el hallazgo de ciertos libros arábigos encontrados fortuitamente en la villa de Muel (Zaragoza) y en otros lugares".
} 
parte de ellos son faltos, y los dos que hai completos están sin fecha. Por lo qual no me ha parecido necesario hacer de cada uno su cédula aparte, siendo del mismo asunto; y quedo siempre a la disposición de Vuestra Señoría».

Explícitamente, Miguel Casiri no encontraba cosa de utilidad en unos textos que trataban mayoritariamente de la religiosidad musulmana de unos moriscos aragoneses. No se trata de una valoración sorprendente: como ya se ha dicho más arriba, una fuerte idea de utilidad pública estaba detrás del intento de recuperación de los antiguos manuscritos árabes; una idea de utilidad que había enfrentado, incluso, a los agentes regios con la Inquisición. Una idea, también, de utilidad pública que sustentaba obras como la Bibliotheca Arabico-Hispana Escurialensis, o proyectos como el de la edición y traducción del Libro de Agricultura, llevada a cabo por uno de los discípulos de Casiri, José Antonio Banqueri, pero que excluía, de hecho, una recuperación sistemática de la cultura morisca.

Se trata de un hecho, en todo caso, que puede ser entendido en una perspectiva quizás más amplia. Resulta significativo que, para el propio Casiri, su obra más importante no haya sido la Bibliotheca Arabico-Hispana Escurialensis, sino su traducción latina del llamado Códice sarraceno, y después Colección canónica árabe, es decir, un códice de la Biblioteca de El Escorial que contenía el texto árabe de los cánones de la iglesia española ${ }^{74}$, y que sería «el monumento más auténtico que tiene la Iglesia de España, y aun la universal, para provar la tradición y el dogma». Para Casiri, la edición y traducción de este códice «apoyaría la religión cathólica en gran parte, avergonzaría a los novadores del siglo 16$\rangle^{75}$; es decir, sería un apoyo para la religión católica pero también un revés para los defensores del pensamiento «moderno», los novatores. Tal consideración de la importancia de este documento para la historia del cristianismo, y del cristianismo oriental, se ve confirmada por un estudioso del s. xx, Paul Massad quien, hablando de Casiri, dice que el trabajo sobre este códice, aunque inédito, fue la obra maestra de

\footnotetext{
${ }^{74}$ Para una revisión reciente de la importancia de este códice, y de las modificaciones que esta colección sufrió para adaptarse al entorno musulmán de al-Andalus, v. Echevarría Arsuaga, A., "Los marcos legales de la islamización: el procedimiento judicial entre cristianos arabizados y mozárabes", Studia Historica. Historia Medieval, 27 (2009), 37-52. Debemos esta referencia a Maribel Fierro.

${ }_{75}$ Para estas citas, v. Archivo BNE, BN 0088/21.
} 
Casiri, y que «los intelectuales árabes y españoles tienen vivas ansias de poder estudiar más de cerca este monumento de la Iglesia Mozárabe», una obra «urgente para nuestra cultura», «la más perfecta colección canónica, no sólo para la Iglesia Oriental, sino también para la Occidental» ${ }^{76}$. Obviamente, desde la perspectiva de Paul Massad, como desde la del propio Casiri, esta colección de cánones era un documento importantísimo de la cultura cristiana árabe, a la que situaba en un lugar fundamental de la entera historia del cristianismo, reivindicando el papel en la misma del cristianismo árabe. Para Casiri, además, era un instrumento de lucha contra la cultura moderna de los novatores. Para él, evidentemente, el árabe era una lengua cristiana. Una afirmación, por cierto, que en España estaba lejos de constituir un hecho evidente aceptado por todo el mundo; y sobre todo a partir de la experiencia morisca.

Sin embargo, esta consideración de la lengua árabe como una lengua cristiana, nos sitúa en una perspectiva amplia, en la que cabe entender también la actividad e intereses de Marcos Dobelio o Casiri, que se comprenden mejor teniendo en cuenta, por ejemplo, experiencias romanas como la del Collegio dei Maroniti o la Congregación de Propaganda Fide, donde la presencia y actividad de personajes como Abraham Ecchelensis fue fundamental para la constitución de un canon teológico y lingüístico árabe cristiano ${ }^{77}$. En este sentido, resulta interesante comprobar cómo Casiri consideraba su propia figura de arabista. Por un lado, él se sentía en competencia con eruditos españoles y europeos en el terreno del conocimiento de lenguas orientales. Así, a la hora de justificar por qué había errado en la interpretación de una breve nota árabe se encontraba en el manuscrito de la Biblia Góthica de la catedral de Toledo, y que le habían enviado de una manera descontextualizada, Casiri decía que él habría dado dicha notita

a varios eruditos que hay en España y Europa, que se jactan con mucha satisfacción saber las lenguas orientales, y con esta presunción publican obras de medallas y inscripciones sin entender estas lenguas ni saberlas leer. A éstos

${ }^{76}$ Massad, P., "Casiri y uno de sus estudios inéditos", Boletín de la Real Academia de la Historia, CXLIV (1956), 15-47, 38-39.

77 V., por ejemplo, Heyberger, B., García-Arenal, M., et al (eds.), L'Islam visto da Occidente. Cultura e religione del Seiciento europeo di fronte all'Islam, Milán-Génova, 2009.

Al-Qanțara (AQ) XXXI 2, julio-diciembre 2010, pp. 611-646 ISSN 0211-3589 
digo que me descifren quatro palabras de lengua y caracteres conocidos, dexando a parte los desconocidos que no conocen y que embíen su lectura exacta y su interpretación, y que un juez docto y prudente juzgue de la suya y de la mía, no ya por la lengua, que tal vez ignora, sino por el sentido solo.

Entre esos jactanciosos eruditos europeos cita precisamente a «Labé Bartholomé Francés, y el famoso Ynglés Swinton», que, al interpretar una misma inscripción maltesa, «no concuerdan entre sí en su lectura ni en su inteligencia. Confiesan que es lengua syriaca que no entienden, ni leen a su arbitrio los caracteres de dicha inscripción sin conocer su alfabeto» ${ }^{78}$; una autoridad, pues, afirmada ante eruditos europeos como John Swinton o l'Abbé Barthélemy, pero también frente a otros falsos eruditos españoles, igualmente inútiles: «Bien sé que hay ciertos sujetos en esta Corte que hacen mucha ostentación de saber las lenguas Hebrea, Árabe y Griega, y que aun publican algunas obrillas poco o nada decorosas a la Nación; pero la jactancia de estos tales es un engaño manifiesto, porque su instrucción en estas lenguas es mui diminuta y superficial, limitada al solo conocimiento de los caracteres y de unos menos y cortísimos principios gramaticales, que de nada sirven ${ }^{79}$. Por supuesto, esta rivalidad con otros supuestos orientalistas tenía también que ver con

78 "Carta de Fr, Domingo Ybarreta a D. Miguel Casiri y contestación de éste sobre una nota arábiga que se halla al fin de una Biblia Góthica de Toledo. Año 1778", en Papeles varios, BNE, mss/13011, f. 169r y ss. La cita merece la pena ser reproducida in extenso: «Pues esta nota árabe es más difícil, o a lo menos de igual dificultad que la inscripción de Malta en que se han interesado tantos sabios de Europa, y tal vez sin haber acertado, y son el Labé Bartholomé Francés, y el famoso Ynglés Swinton, que no concuerdan entre sí en su lectura ni en su inteligencia. Confiesan que es lengua syriaca que no entienden, ni leen a su arbitrio los caracteres de dicha inscripción sin conocer su alfabeto. Confieso ingenuamente que yo no puedo leer una escritura de qualesquiera lengua sin el conocimiento preciso de su alfabeto que me da la figura de cada letra y su valor, pues el que no entiende la lengua syriaca ni conoce su alfabeto, cómo podrá leer y entender el significado de esta palabra [signo confuso], cómo sabrá el número de las letras que la componen, cómo sabrá sus figuras, potestad y valor, cómo sabrá si entre las consonantes hai vocales, y finalmente, cómo sabrá que una misma letra tiene dos o tres figuras como sucede en todas las lenguas. Dexo esto al juicio y examen de los verdaderos sabios y prudentes amantes de la verdad y no del aplauso del vulgo ignorante. Y digo más, cómo podrá uno, aunque conozca el alfabeto latino, leer y explicar una inscripción latina si no sabe esta lengua, ni su erudición. Lo mismo digo de las inscripciones de otras lenguas, quanto más de las lenguas cuios caracteres ignoramos y su lengua. Yo apelo a la experiencia, yo daré a estos eruditos a la moda, no inscripciones largas, sino breves cláusulas, estoi seguro que no las leerán ni las entenderán. Escribiré un tomo en que demostraré la verdad de lo que digo».

${ }^{79}$ BNE-A, BN 0088/09.

Al-Qanțara (AQ) XXXI 2, julio-diciembre 2010, pp. 611-646 ISSN 0211-3589 
el dominio de la lengua árabe clásica, que representaba el auténtico campo de saber útil para la nación, y no el de la lengua vulgar, que era el único conocimiento de algún otro de sus pretendidos competidores ${ }^{80}$.

Para completar este perfil orientalista de Casiri en su entorno español y europeo, conviene quizás aludir al tipo de libros que constituían el núcleo de su formación erudita. Una pista de este aspecto nos la puede proporcionar la lista de libros que Casiri tomó prestados de la Biblioteca Real. Así, para elaborar su Bibliotheca Arabico-Hispana Escurialensis, tuvo a su disposición durante los largos años de trabajo un repertorio de fuentes árabes célebres, como las obras de Ibn al-Jatīib, Ibn al-Abbār, Ibn 'Amīra, Ibn al-'Awwām o Ibn Baškuwāl. Pero éste no es el único lote de libros que Casiri había pedido prestados de la Biblioteca Real: una «lista de libros, muebles y pinturas de la Real Bibliotheca que tiene en su poder Don Miguel Casiri» de 1751 incluye una nómina de otros 17 de libros de la Biblioteca en poder del orientalista maronita. Además de alguna obra más general (el Diccionario de Nebrija, el Onomasticum arabicum de Felice Felici o un Dictionarium de Ambrogio Calepino), esta lista incluye algunos de los títulos más representativos del orientalismo europeo de los Ss. XVI y XVII: el Diccionario árabelatino de Golius, las obras de Pococke, D'Herbelot, Gravius, Gabriel Sionita, Erpenius, la edición y traducción de la Geografía de alIdrīsī, la Descrizione de León Africano e, incluso, la Lingua aegiptiaca restituta de Athanasius Kircher ${ }^{81}$. Una selección, en fin, que da una pista acerca de la formación orientalista de Casiri, y su familiaridad con lo más importante de la erudición europea del s. XVII, y, en algún caso, anterior.

${ }^{80}$ «No me parece presunción si digere que en estos pocos años he trabajado más que Don Andrés de San Juan en los muchos que ha servido. Además de haver traducido y explicado varias inscripciones y medallas antiguas, he ordinado y resumido más de mil y ochocientos manuscritos arábigos de la Bibliotheca del Escurial, en cuya impresión estoi entendiendo. He enseñado árabe a algunos sugetos, que después podrán servir mucho a la Nación. Nada de esto ha hecho ni puede hacer Don Andrés de San Juan ni su sobrino; porque sólo saben la lengua árabe vulgar, que no sirve para tales obras», Memorial de Miguel Casiri a Ricardo Wall, 1752, citado por Massad, "Casiri", 31. Sobre las malas relaciones entre Casiri y Juan Amón de San Juan, v. Torres, MP., "Pablo Hodar, escribiente de árabe en la Biblioteca Real, y su relación con dos falsificaciones del XVIII", Al-Andalus Magreb, 6 (1998), 209-235.

${ }^{81}$ BNE-A, 0435/11. 
Así se puede entender mejor, quizás, el comentario de Casiri acerca de que su traducción latina del Códice sarracénico podía ayudar a avergonzar «a los novadores del siglo 16». A pesar de la alusión a ese siglo, el término novatores designa, como se sabe, a un grupo de pensadores, científicos e historiadores de finales del s. XVII y principios del s. XVIII, comprometidos, en el caso español, con la introducción en España de la ciencia y la filosofía «modernas», y cuya acción representa una especie de pre-Ilustración local ${ }^{82}$. Que Casiri considerase que ese antiquísimo códice árabe cristiano hispano podría servir para contrarrestar el avance del pensamiento moderno demuestra, por una parte, la relación entre la lengua árabe y la posibilidad de escribir una historia sagrada de España (relación puesta de manifiesto, por ejemplo, por el asunto de los Plomos del Sacromonte, evocado más arriba a propósito de la figura de Marcos Dobelio); por otra parte, la afirmación de Casiri ponía de manifiesto la relación entre erudición oriental y escepticismo. No es casual, por ejemplo, que alguno de los novatores más ilustres fuese, también, un orientalista aficionado ${ }^{83}$. Obviamente, en Casiri se producía de nuevo esta conjunción entre orientalismo y cristianismo, de larga historia en Europa, y que llevó al aquilatamiento de una lengua árabe cristiana, cuya referencia fundamental era la tradición maronita. En buena medida, el conflicto de los Plomos del Sacromonte cuando fueron examinados por arabistas orientales, o cuando fueron llevados a Roma, era el de la contradicción entre ese cristianismo árabe oriental y un pretendido cristianismo árabe hispano, producido por moriscos, en una lengua árabe lingüísticamente teñida de dialectal y doctrinalmente teñida de Islam ${ }^{84}$. Este hecho determina, sin duda, la forma en que la cultura morisca fue aprehendida por esta erudición orientalista de los cristianos orientales, que no veía en ella ni la expresión de una tradición árabe cristiana ni tampoco el lugar de producción de obras útiles para la república. Esta consideración, sin embargo, tiene un contrapunto importante, como queda dicho

${ }^{82}$ Véase, por ejemplo, Pérez Magallón, J., Construyendo la modernidad: la cultura española en el tiempo de los novatores (1675-1725), Madrid, 2002.

${ }^{83}$ Nosotros hemos puesto de manifiesto esta relación en figuras como Nicolás Antonio o el Marqués de Mondéjar. V. García-Arenal y Rodríguez Mediano, Un Oriente español.

${ }^{84}$ García-Arenal, M., "The Religious Identity of the Arabic Language and the Affair of the Lead Books of the Sacromonte of Granada", Arabica, 56 (2009), 495-528. 
más arriba: el uso de obras moriscas por parte de protestantes y escépticos en sus polémicas católicas, como es el caso de la obra del morisco de Pastrana Muhammad Alguazir, y que, finalemente, sirve para trazar los contornos amplios de una historia intelectual de la lengua árabe en Europa, en la que el hecho morisco es interpretado en función de sus variables lingüísticas y doctrinales, a partir de la constitución de una disciplina erudita (el orientalismo), en medio de las polémicas religiosas entre Reforma y Contrarreforma, en fin, a partir de la historia de la disidencia religiosa y del escepticismo en la Europa Moderna.

Recibido: $25 / 04 / 2010$

Aceptado: 21/06/2010 